\title{
Parathyroid tumors and related disorders
}

\author{
Ronald A DeLellis ${ }^{1,2}$ \\ ${ }^{1}$ Warren Alpert Medical School of Brown University, Providence, RI, USA and ${ }^{2}$ Department of Pathology, \\ Rhode Island Hospital and The Miriam Hospital, Providence, RI, USA
}

\begin{abstract}
Primary hyperparathyroidism (P-HPT) is a common endocrine disorder that occurs as a result of adenomas $(80-85 \%)$, hyperplasias $(10-15 \%)$ or carcinomas $(<1 \%)$ of the parathyroid glands. Molecular genetic analyses of heritable P-HPT syndromes have provided considerable insight into the understanding of sporadic parathyroid tumors and hyperplasias. This review will focus on the criteria for classification of parathyroid proliferative disorders and will highlight our understanding of these lesions at the molecular level. Advances in radiological imaging techniques together with the rapid intraoperative parathyroid hormone assay will be reviewed with respect to current treatment approaches for P-HPT. Modern Pathology (2011) 24, S78-S93; doi:10.1038/modpathol.2010.132
\end{abstract}

Keywords: carcinoma; HPT-JT syndrome; MEN-1; molecular diagnostics; parafibromin; parathyromatosis; 99mTc-sestamibi

Primary hyperparathyroidism (P-HPT) is an ancient disease with one of the earliest documented cases described in a 25- to 35-year-old woman discovered in an early Neolithic cemetery. ${ }^{1}$ Plain films and CT scans showed changes consistent with HPT, including significant demineralization of the skeleton with a 'salt and pepper' appearance of the skull. Histological examination revealed significant enlargement of the Haversian canals in compact bone, broad based endosteal resorption zones and 'cookie bite' defects of the trabecular surface of cancellous bone.

In the first quarter of the 20th century, reports of two patients (Albert G (Vienna) and Captain Charles Martell (Boston)) identified tumors of the parathyroid glands as being responsible for widespread demineralization of the skeleton, cystic disease of bone and recurrent renal stones. ${ }^{2,3}$ The case of Captain Charles Martell is particularly well known. This patient was subjected to multiple cervical explorations in attempts to find a parathyroid tumor that was ultimately located within the mediastinum. Amazingly, Captain Martell lost 7 inches in height as a result of severe bone disease during the 13-year course of his illness.

Correspondence: Dr RA DeLellis, MD, Department of Pathology, Rhode Island Hospital, 593 Eddy Street, Providence, RI 02903, USA.

E-mail: rdelellis@lifespan.org

Presented in part at the Annual Meeting of the US and Canadian Academy of Pathology, 24 March 2010.

Received 17 June 2010; accepted 18 June 2010

\section{Epidemiology and clinical aspects}

Primary hyperparathyroidism emerged from relative obscurity before the 1970s to become the third most common endocrine disorder in more recent times. ${ }^{4,5}$ This dramatic change was brought about by the introduction of automated serum calcium measurements in mid-1974. As a result of this type of screening, the age-adjusted incidence rates of P-HPT increased from 15.8 (1970-74) to 82.5 cases (1974-82) per 100000 person years for males and females. ${ }^{6}$ Since that time, the incidence rates have decreased. Numerous hypotheses have been advanced to explain the progressive decline, including the 'sweeping' effects of screening, the use of estrogen replacement in postmenopausal women, calcium and vitamin $\mathrm{D}$ dietary supplementation and the use of therapeutic head and neck irradiation in the 1930s and 1940s, which could have accounted for the 'epidemic' of hyperparathyroidism observed in the late 1970s and 1980s.

Primary hyperparathyroidism predominates in women with a female to male ratio of $3-4: 1$ and an average age at diagnosis of 55 years. The clinical presentations in recent series have changed from those dominated by severe bone and kidney disease to those characterized by lack of symptoms or by fatigue, weakness, depression and gastrointestinal symptoms, including constipation, nausea and dyspepsia. ${ }^{5}$

The term P-HPT refers to the inappropriate overproduction of parathyroid hormone (PTH), resulting in abnormal calcium homeostasis. High levels of 

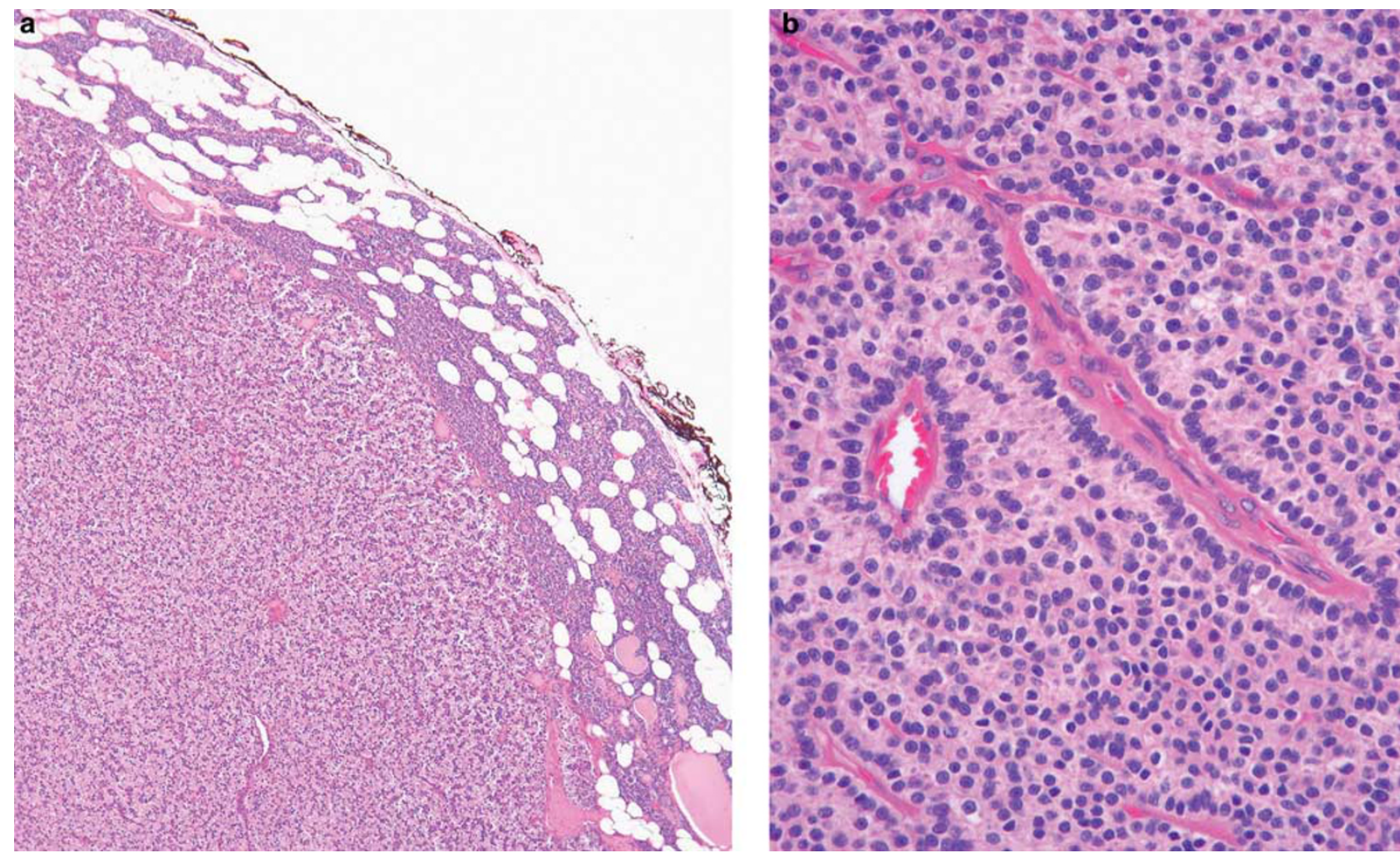

Figure 1 (a) Parathyroid adenoma, chief cell type. The tumor (left) is surrounded by a rim of normocellular parathyroid gland. (b) Parathyroid adenoma, chief cell type. The tumor cells have round to ovoid nuclei with densely stained chromatin and a palisaded arrangement around blood vessels.

PTH lead to increased renal resorption of calcium, phosphaturia, increased synthesis of $1,24(\mathrm{OH})_{2} \mathrm{D}_{3}$ and increased bone resorption. ${ }^{5}$ Typically, patients have evidence of hypercalcemia, hypophosphatemia, hypercalciuria, increased levels of PTH and normal levels of PTH-related protein. Occasional patients with normocalcemic hyperparathyroidism have also been described. ${ }^{7}$ P-HPT may result from adenoma/single-gland disease (80-85\%), hyperplasia/multi-gland disease $(10-15 \%)$ or carcinoma $(<1 \%){ }^{8}$ If the frequencies of these disorders are determined by intraoperative PTH (IOPTH) assays with postoperative restoration of eucalcemia, hyperplasia becomes considerably less common. ${ }^{9}$ Rare cases of apparent P-HPT may result from the paraneoplastic production of PTH by nonparathyroid tumors, ${ }^{10}$ whereas most cases of malignancyassociated hypercalcemia result from the paraneoplastic production of PTH-related protein. ${ }^{11}$

\section{Parathyroid adenoma}

Parathyroid adenomas are benign neoplasms composed of chief cells, oncocytes or transitional oncocytes with frequent admixtures of these cell types. ${ }^{12,13}$ Although most adenomas involve a single gland, occasional cases of double adenomas have been reported. ${ }^{14}$ Double adenomas appear to have a nonuniform anatomic distribution with a predilection for the superior parathyroid glands, which are remnants of the fourth branchial pouch. ${ }^{15}$ The average weight of adenomas in patients without significant bone disease is $\sim 1 \mathrm{~g}$ with many $<0.5 \mathrm{~g}$, whereas tumors in patients with significant bone disease tend to be larger. The term 'microadenoma' refers to tumors weighing $<0.1 \mathrm{~g}$. Foci of cystic change tend to occur in large adenomas and are relatively common in the tumors associated with the hyperparathyroidism-jaw tumor (HPT-JT) syndrome, as discussed in a subsequent section.

Microscopically, most adenomas are composed of chief cells. Although microadenomas are nonencapsulated, larger tumors are usually surrounded by a fibrous capsule. A rim of normocellular parathyroid tissue is often present at the periphery of adenomas, although this feature may not be apparent in large tumors (Figure 1a). The component cells may be arranged in cords, nests, sheets and follicles and frequently have a palisaded arrangement around blood vessels (Figure 1b). The nuclei are round and densely stained and are typically larger than those present in the adjacent non-neoplastic parathyroid tissue. Scattered hyperchromatic and pleomorphic nuclei exhibiting so-called 'endocrine atypia' are relatively common, as are multinucleated tumor cells ${ }^{13}$ (Figure 2). Mitotic activity may be present in up to $70 \%$ of adenomas ${ }^{16}$ and the proliferative fraction, as 


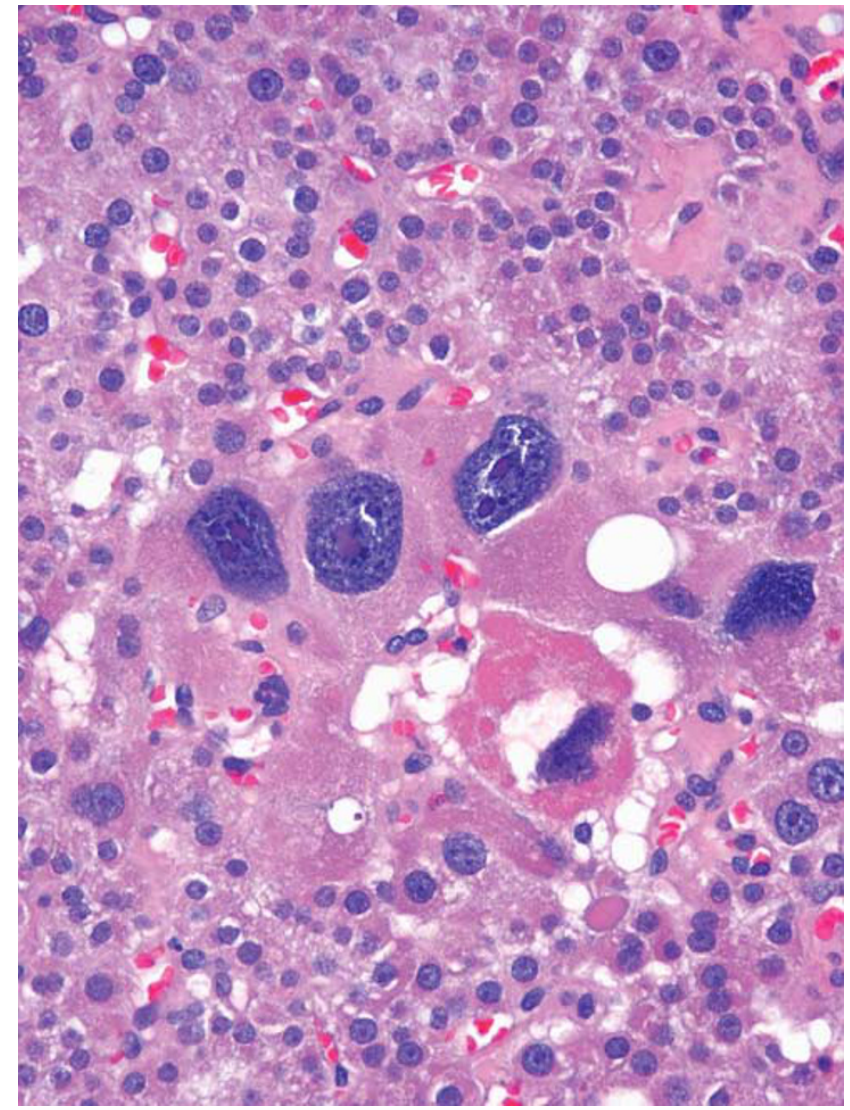

Figure 2 Parathyroid adenoma. Scattered groups of tumor cells have markedly enlarged hyperchromatic nuclei with large nucleoli (endocrine atypia) and abundant eosinophilic cytoplasm.

assessed with Ki-67, is generally $<4 \%{ }^{17-19}$ The tumor cells are positive for cytokeratins, PTH and chromogranin A, whereas stains for thyroglobulin and thyroid transcription factor-1 are negative.

Some parathyroid adenomas may have a prominent follicular architecture (Figure 3a). The follicles contain a colloid-like material and may be distinguished from normal and neoplastic thyroid tissue by the presence of birefringent calcium oxalate crystals that may be present in the latter. ${ }^{20}$ This approach is particularly useful during frozen examination. Adenoma variants include oncocytic adenomas, (Figure 3b) lipoadenomas (hamartomas) (Figure 3c) and clear cell adenomas (Figure 3d). ${ }^{12,13}$ Lipoadenomas are characterized by the presence of abundant stromal elements including mature fat cells with myxoid change and areas of fibrosis and lymphocytic infiltration. Very rare adenomas may assume spindle cell features or may have a papillary architecture.

Adenomas represent clonal proliferations and are similar in this regard to a significant proportion of primary and secondary parathyroid hyperplasias. ${ }^{21,22}$ One of the molecular abnormalities described in these tumors involves the cyclin D1 (CCND1/PRAD1) oncogene on 11q13. Overexpres- sion of this oncogene results from pericentric inversion of chromosome $11 \mathrm{p}$, with placement of the CCND1 gene under the control of tissue-specific enhancer elements of the PTH gene promoter sequences. Translocations of this type were initially reported in $5 \%$ of adenomas. FISH analyses have reported translocations in up to $8 \%$ of cases. ${ }^{21}$ However, overexpression of cyclin D1 occurs in up to $40 \%$ of adenomas, suggesting mechanisms other than translocations for overexpression. Such mechanisms could include amplification, rearrangements with other enhancers or promoters or transcriptional activation.

The MEN1 gene on 11q13 is a tumor suppressor that encodes menin. Mutations of this gene are responsible for the development of the type1 multiple endocrine neoplasia (MEN1) syndrome. ${ }^{23,24}$ Loss of one MEN1 allele has been observed in up to $40 \%$ of sporadic parathyroid adenomas, with an inactivating mutation of the second allele occurring in $50 \%$ of these tumors. ${ }^{21,25}$ Abnormalities of the MEN1 gene have also been observed in small adenomas, suggesting that alterations of this gene represent an early event in parathyroid tumorigenesis.

Other genes including $R E T$, the vitamin $\mathrm{D}$ receptor and the calcium-sensing receptor $(C a S R)$ have also been studied for pathogeneic mutations in adenomas, but none has been found to date. ${ }^{22}$ Comparative genomic hybridization studies have shown loss of $11 \mathrm{q}$ as the most frequent alteration in adenomas. In addition, losses of $1 p, 6 q, 9 p, 11 p, 13 q$ and $15 q$ and gains in $7,16 p$ and $19 p$ occur commonly. ${ }^{26}$

\section{Preoperative localization and surgical treatment}

Parathyroid surgery has evolved from conventional open parathyroidectomy, with exploration of all four parathyroid glands, to minimal access open or endoscopic parathyroidectomy. ${ }^{27}$ This evolution was made possible by the development of highresolution radiological techniques and the development of the rapid IOPTH assay. Sonography and technetium-99m-sestamibi ( ${ }^{99 m}$ Tc-sestamibi) scintigraphy are the most commonly used imaging techniques for the demonstration of parathyroid lesions. Comparative studies have revealed similar sensitivities and specificities for the detection of adenomas with these approaches. Adenomas are almost always hypoechoic to the overlying thyroid gland on grayscale imaging. ${ }^{28}$ Color and power Doppler imaging frequently show a characteristic extrathyroidal feeding vessel that enters the gland at one of the poles and frequently branches around the tumor producing a rim-like effect. The sensitivity of sonography for the detection of single adenomas ranges from 72 to $89 \%$, whereas sensitivities for multiglandular disease are considerably lower.

${ }^{99 m}$ Tc-sestamibi is the most commonly used radiotracer for imaging of the parathyroid gland. ${ }^{29}$ The 

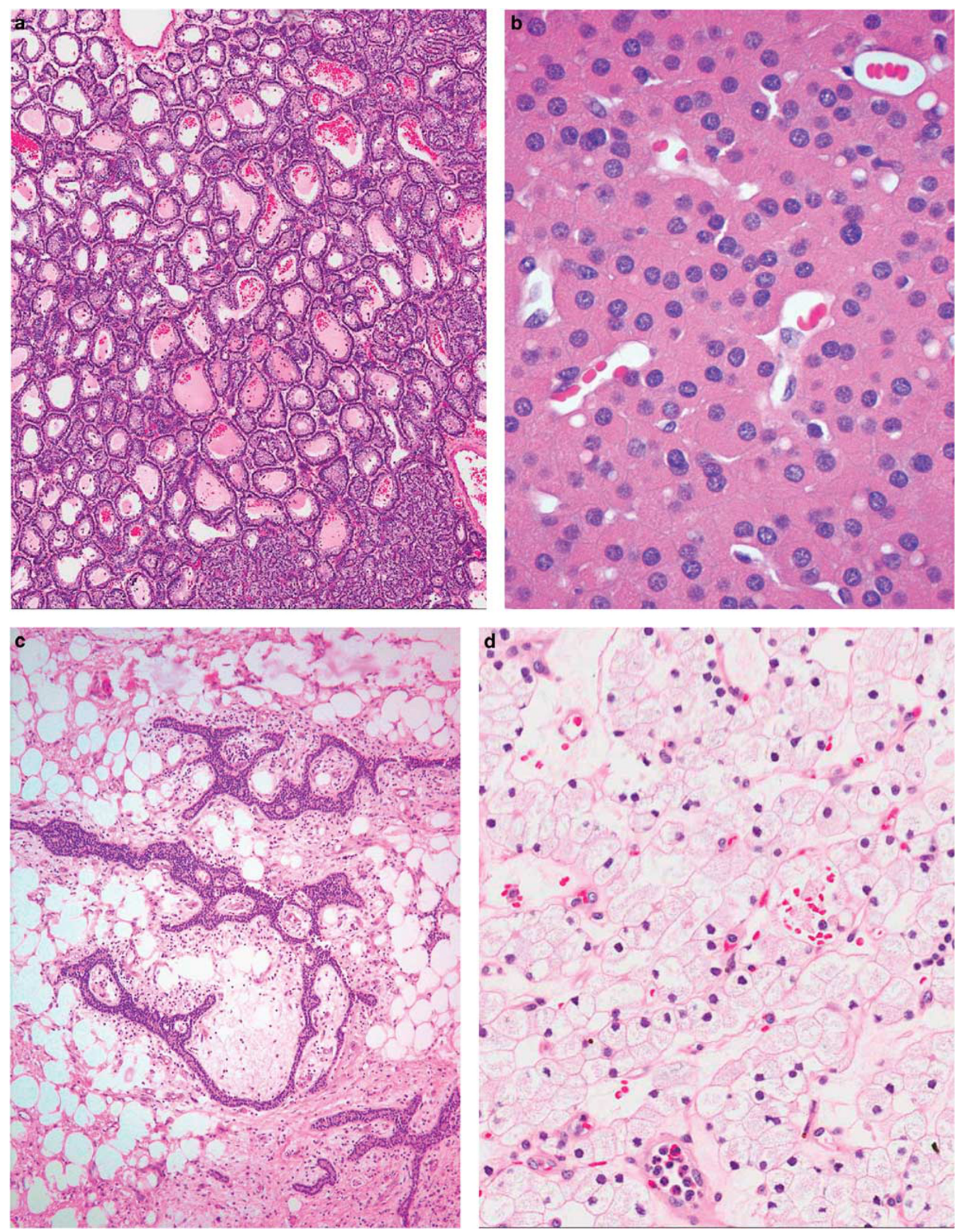

Figure 3 (a) Parathyroid adenoma, chief cell type. This tumor has a predominant follicular architecture with colloid-like material in many of the follicles. (b) Parathyroid adenoma, oncocytic type. The tumor cells have abundant granular eosinophilic cytoplasm. (c) Parathyroid lipoadenoma (hamartoma). The tumor cells form branching cord that are surrounded by fat cells with areas of fibrosis and chronic inflammatory cells. (d) Parathyroid adenoma, water-clear cell type. The tumor cells have small nuclei with dense chromatin and abundant vacuolated cytoplasm. 
tracer is concentrated both by the thyroid and parathyroid glands, but hyperactive parathyroid glands typically have more avid uptake of the

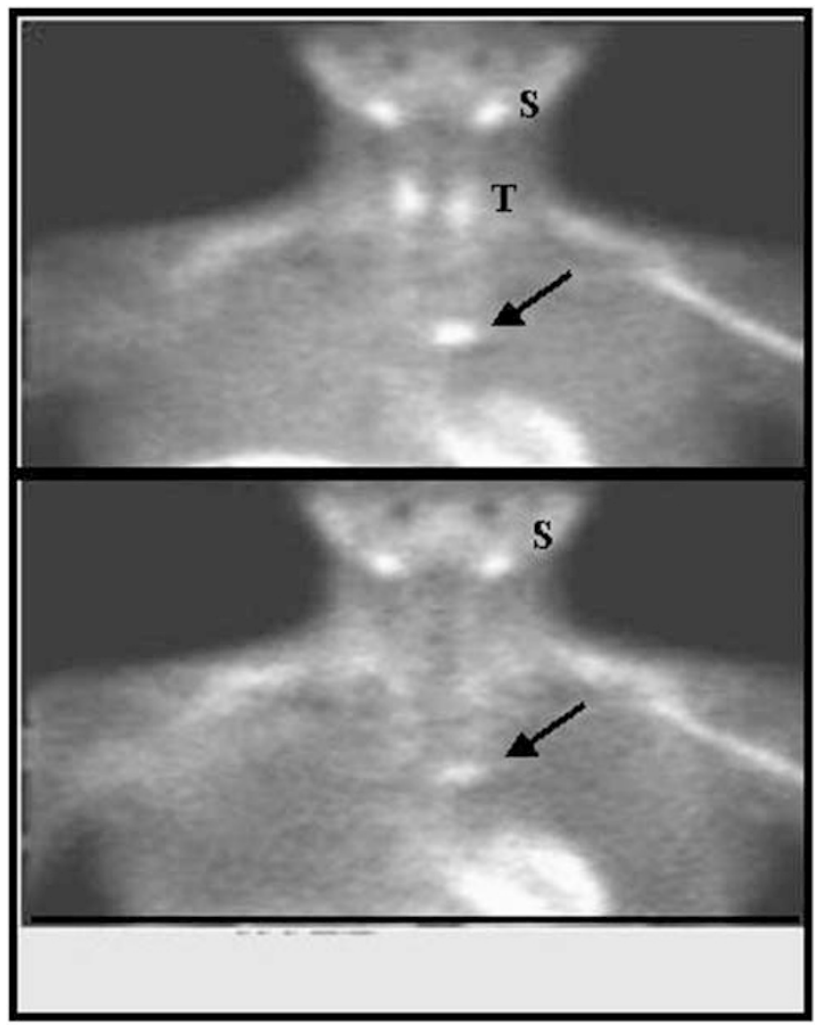

Figure 4 Delayed imaging ${ }^{99 m}$ Tc-Sestamibi scan (grayscale image). Top panel, initial image. Bottom panel, delayed image taken after 2 hours. Arrow indicates parathyroid adenoma. S, salivary gland, $\mathrm{T}$, thyroid gland. tracer and retain it longer than the adjacent thyroid tissue. On delayed imaging at 2 hours, the tracer is retained by abnormal parathyroid tissue but washes out of the thyroid (Figure 4). Single photon emission tomography (SPECT) with a pinhole collimator can further help to discriminate parathyroid and thyroid tissue. The sensitivity of ${ }^{99 m} \mathrm{Tc}$-sestamibi using SPECT ranges from 68 to $95 \%$ for the detection of single-gland disease, but this approach is considerably less sensitive for the identification of multiglandular disease. Modifications of the original sestamibi scan protocols include the use of radioactive iodine to subtract the thyroid image.

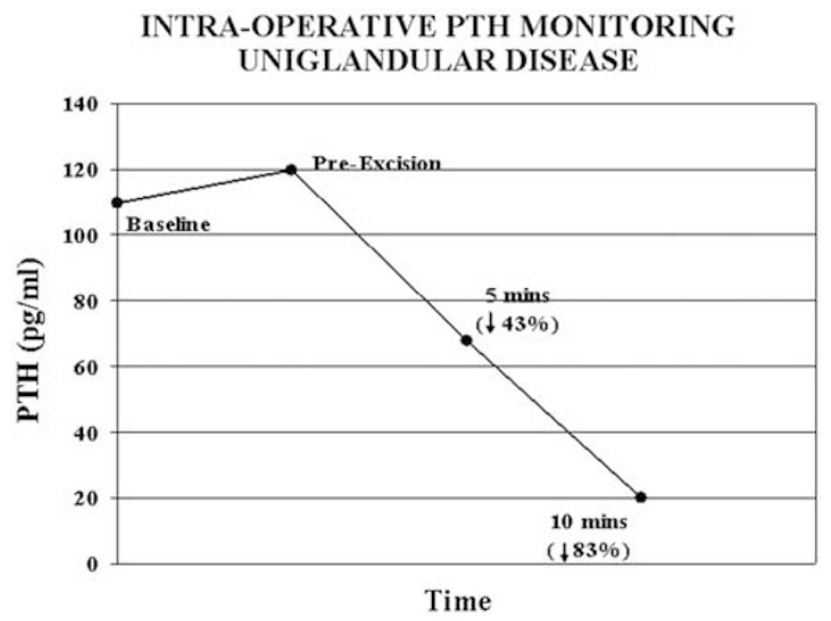

Figure 5 Intraoperative parathyroid hormone monitoring in a patient with uniglandular disease (parathyroid adenoma). There is a $>50 \%$ reduction in parathyroid hormone levels 10 min after excision of the abnormal gland.

Table 1 Heritable hyperparathyroidism syndromes

\begin{tabular}{|c|c|c|c|}
\hline Syndrome & Gene (locus) & $\begin{array}{l}\text { Parathyroid } \\
\text { pathology* }\end{array}$ & Other features \\
\hline $\begin{array}{l}\text { Multiple endocrine } \\
\text { neoplasia } 1 \text { (MEN) } 1\end{array}$ & MEN1 (11q13) & Hyperplasia (90\%) & $\begin{array}{l}\text { Pituitary adenomas, pancreatic endocrine } \\
\text { tumors, carcinoid tumors, adrenocortical tumors, } \\
\text { facial angiofibromas, collagenomas, lipomas }\end{array}$ \\
\hline $\begin{array}{l}\text { Multiple endocrine } \\
\text { neoplasia 2a (MEN 2a) }\end{array}$ & RET (10q11.2) & Hyperplasia (30\%) & Medullary thyroid carcinoma, pheochromocytoma \\
\hline $\begin{array}{l}\text { Familial hypocalciuric } \\
\text { hypercalcemia (FHH) }\end{array}$ & $\begin{array}{l}\text { CaSR/heterozygous } \\
\text { (3q13.3q21) }\end{array}$ & Mild hyperplasia & \\
\hline $\begin{array}{l}\text { Neonatal severe primary } \\
\text { hyperparathyroidism }\end{array}$ & $\begin{array}{l}\text { CaSR/homozygous } \\
\text { (3q 13.3q21) }\end{array}$ & Hyperplasia & \\
\hline
\end{tabular}

Hyperparathyroidism-jaw tumor (HPT-JT) syndrome

Familial isolated hyperparathyroidism

Familial hypercalcemic hypercalcuria (autosomal dominant mild HPT)
HRPT2 (1q25-q32)

MEN1 (11q13); CaSR

(3q13.3-q21); HRPT2

(1q25-q32)

CaSR
Ossifying jaw fibromas; renal cysts, carcinomas; Wilms' tumor
Cystic adenomas,

Hyperplasia, carcinoma

Hyperplasia, adenoma

*Although the term "hyperplasia" has been used to describe the parathyroid lesions in these syndromes, they are more closely related to adenomas since they represent clonal proliferations. For this reason, it may be preferable to refer to these cases as "multiglandular parathyroid disease" rather than "hyperplasia". 

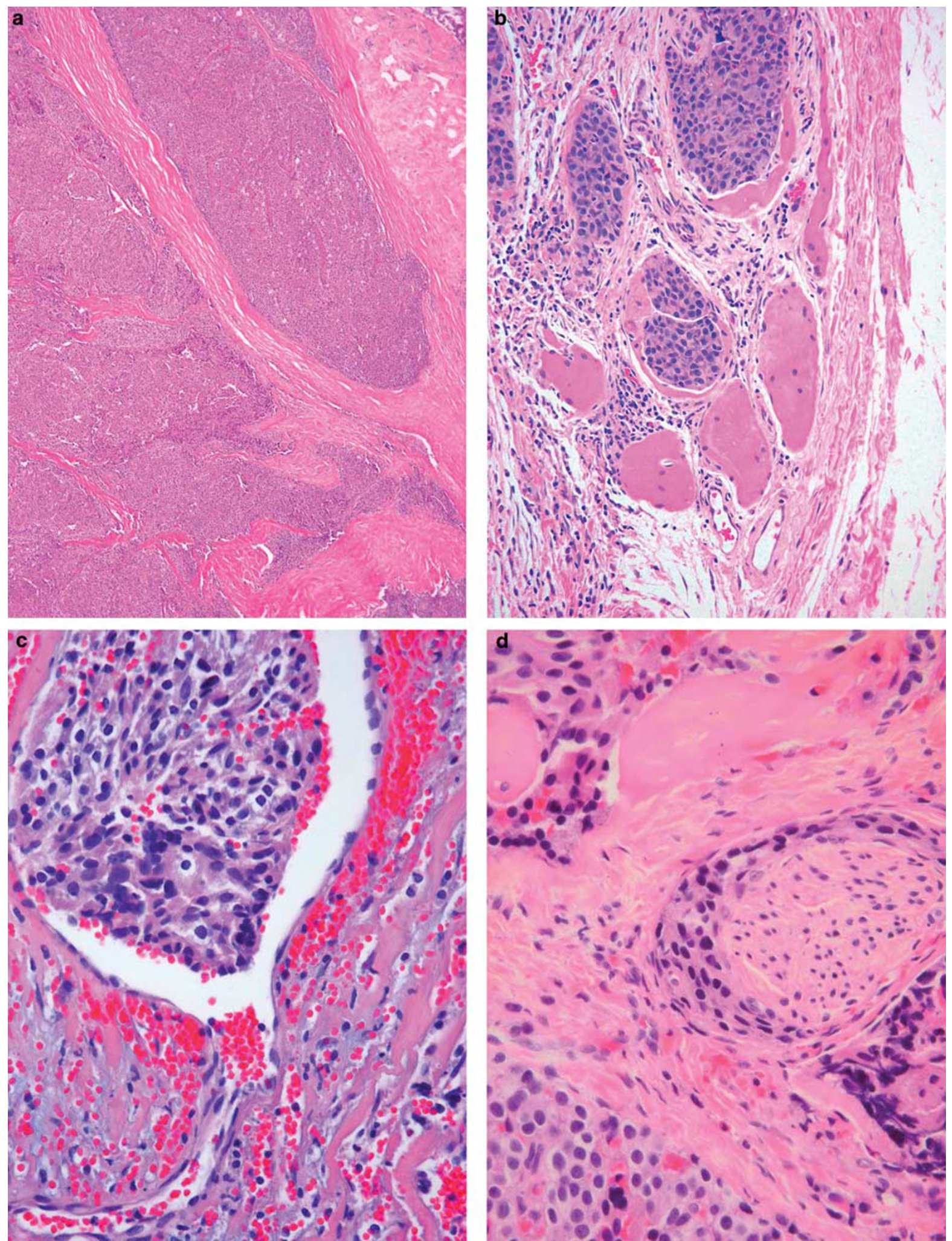

Figure 6 (a) Parathyroid carcinoma. The tumor is divided into cellular nodules by dense bands of fibrous connective tissue. (b) Parathyroid carcinoma. The tumor has invaded the adjacent skeletal muscle. (c) Parathyroid carcinoma. The tumor has invaded a vascular channel. (d) Parathyroid carcinoma. The tumor has invaded the perineural space.

The development of the rapid IOPTH assay was a major advance, as this approach could accurately confirm or refute the preoperative localization studies. $^{30}$ Overall, in-lab turnaround time for this assay averages $13-15 \mathrm{~min}$. Multiple studies have confirmed the ability of IOPTH to guide 

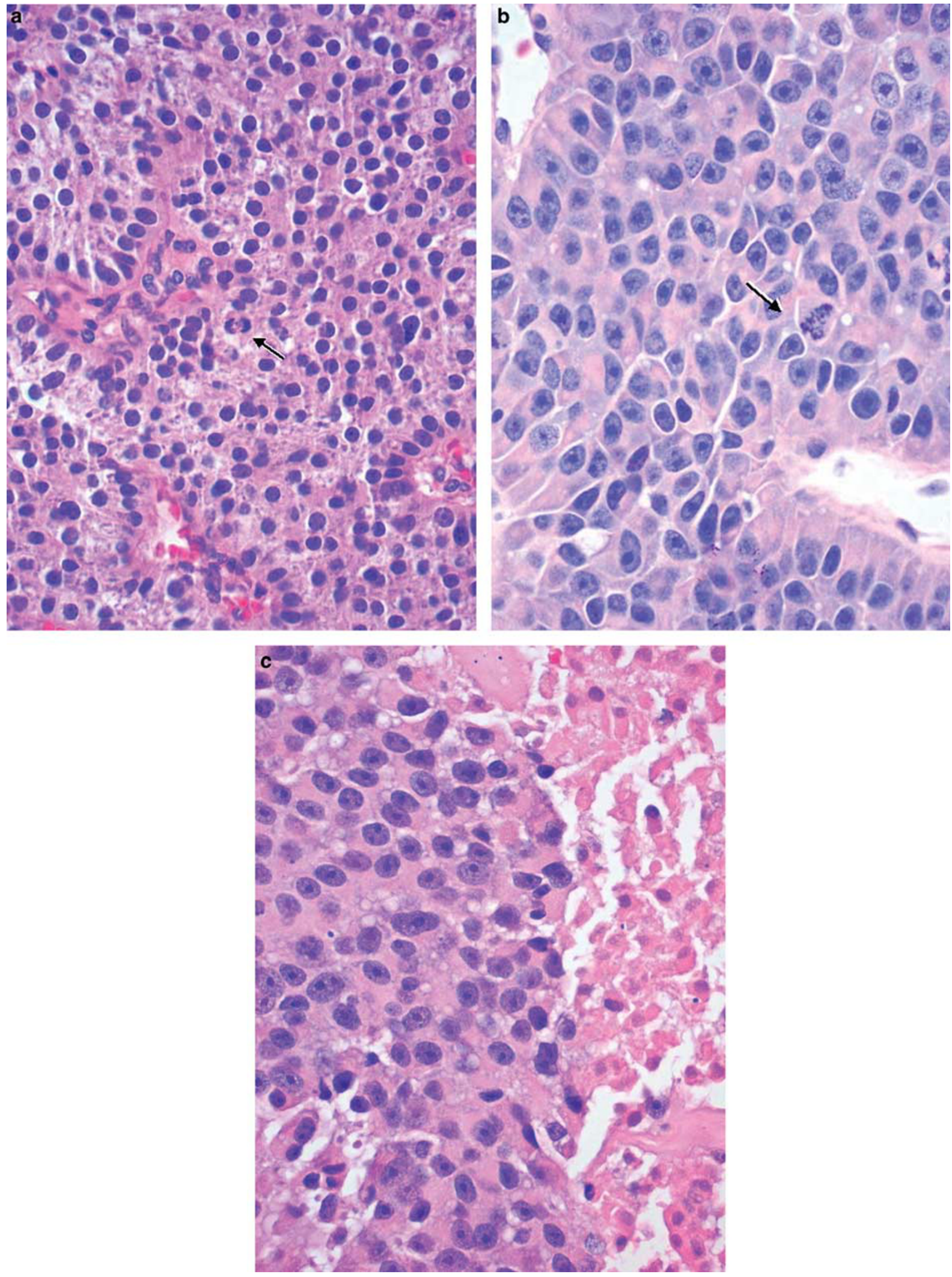

Figure 7 (a) Parathyroid carcinoma. This tumor is composed of mildly pleomorphic cells. A single mitotic cell (arrow) is present. Overall mitotic rate was less than 1 per 50 high-power fields. (b) Parathyroid carcinoma. The tumor cells have macronucleoli with an atypical mitotic figure (arrow) present in this field. (c) Parathyroid carcinoma. This tumor has multifocal areas of necrosis (right). 
a

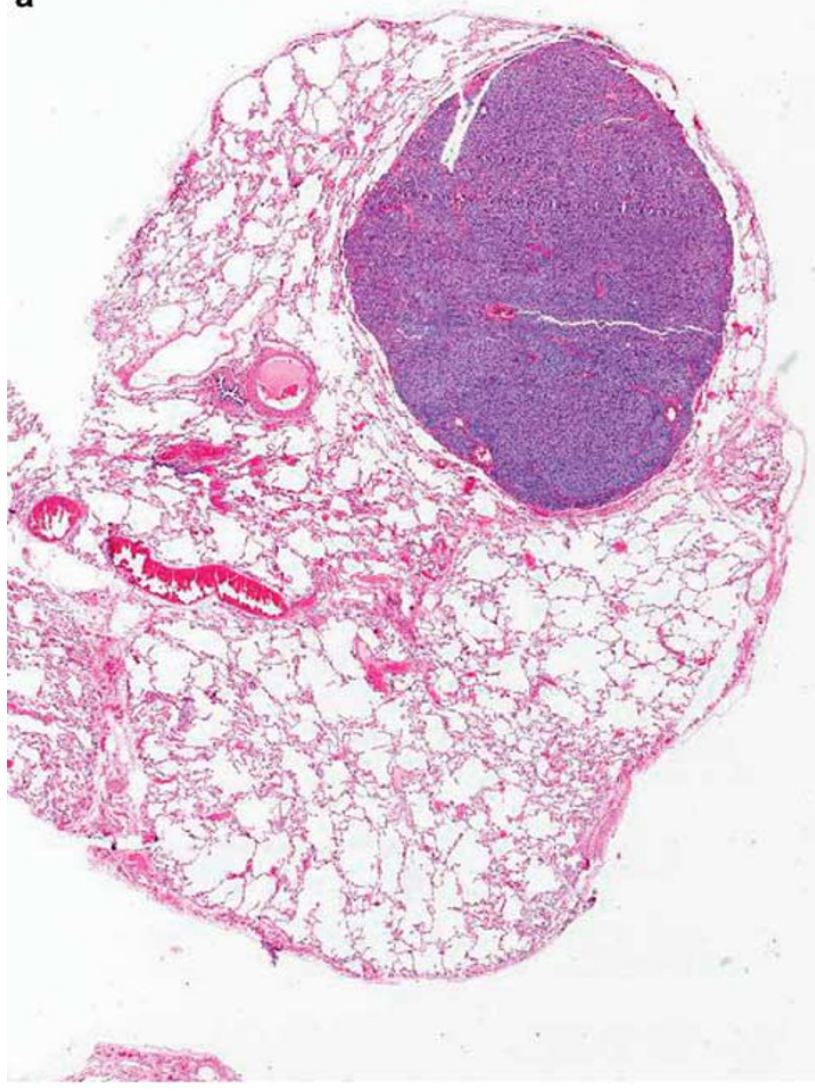

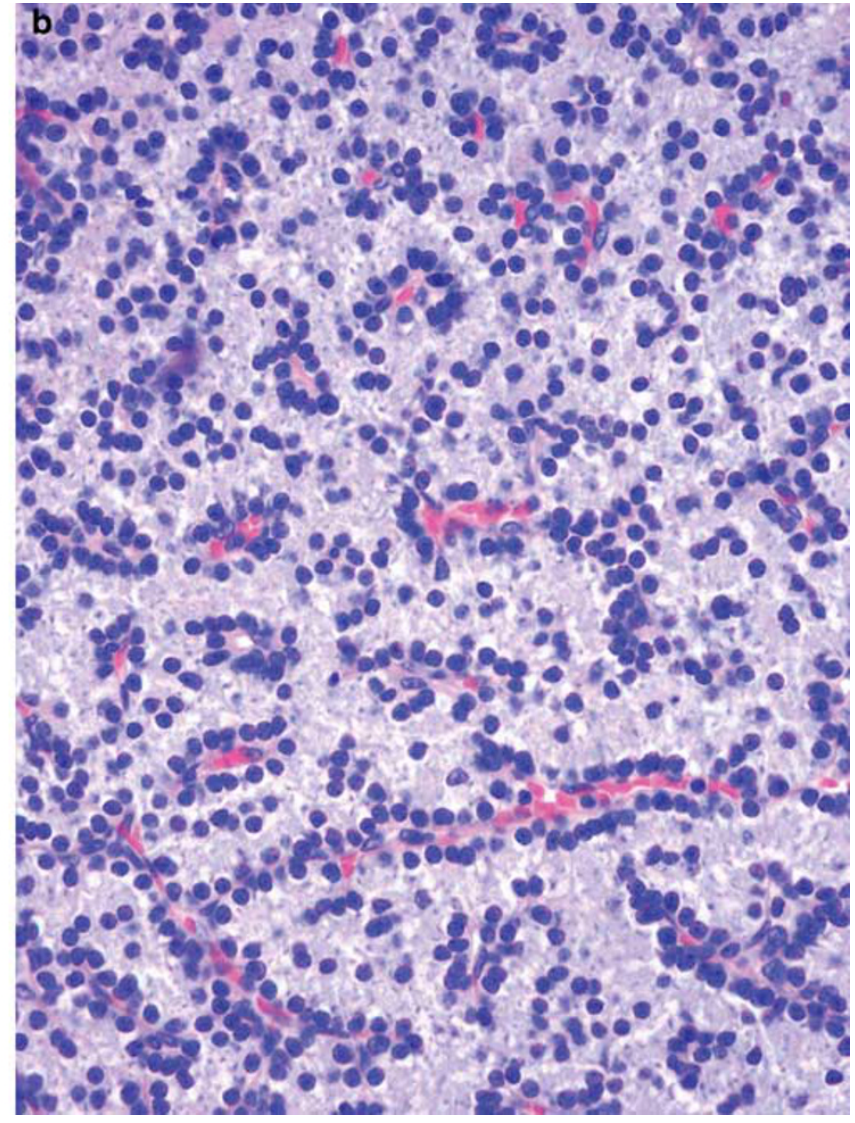

Figure 8 (a) Metastatic parathyroid carcinoma in lung. The metastatic tumor formed multiple circumscribed nodules. (b) Metastatic parathyroid carcinoma (same case as panel a). This tumor is indistinguishable from a parathyroid adenoma.

the surgeon's intraoperative decision making by accurately predicting whether or not additional hypersecreting glands remain in the neck after removal of the gland(s) identified by preoperative localization. The success of this approach is based on the fact that PTH has a half-life of $<5$ min. A drop in IOPTH of $\geqslant 50 \%$ from the baseline or preexcision value at $10 \mathrm{~min}$ after gland excision is generally accepted as the criterion by which the surgeon could conclude that all abnormal glands had been removed, without having to identify all four glands (Figure 5). In a series of more than 600 cases performed by the traditional four-gland approach or by a minimally invasive procedure, the rates for double adenomas and hyperplasia were 11 and $7 \%$, respectively, for the former approach and 5.1 and $1.6 \%$, respectively, for the latter. ${ }^{31}$ These findings underscore the fact that a subset of patients had enlarged glands that were not identified by sestamibi, ultrasound or IOPTH, but which would have been discovered with the traditional four-gland approach. The question remains as to whether enlarged glands that are not hypersecreting at the time of initial surgery will cause recurrent hyperparathyroidism in the future. The 6-month followup studies from the University of Miami have shown a cure rate of $98 \%$ with a focused approach. ${ }^{32}$ In some series, a false-positive drop of PTH of $>50 \%$ has been noted in $2-3 \%$ of patients, whereas a similar proportion of patients have had a falsenegative drop in PTH at 10 min. ${ }^{33,34}$

Occasional normocalcemic patients may have increased levels of PTH at 1-5 years after apparent curative surgery. ${ }^{35}$ At present, there is no evidence that postoperative increases in PTH levels are indicative of surgical failure. Potential mechanisms of PTH elevation in the setting of normocalcemia include vitamin $\mathrm{D}$ deficiency, hungry bone syndrome and PTH resistance.

\section{Parathyroid carcinoma}

Parathyroid carcinoma (PT-CA) is a rare tumor, which accounts for $<1 \%$ of cases of P-HPT in most large series. ${ }^{36}$ However, there is considerable variation in the incidence of this tumor in different parts of the world, with rates as high as $5 \%$ in some series. ${ }^{37}$ Although this variability may represent true geographic differences, an alternative explanation may be related to differences in pathological criteria for the diagnosis of these tumors. There is little information on the etiology of PT-CA, but prior radiation does not seem to be a significant factor. Rare cases of PT-CA have been reported in patients with long-standing secondary hyperparathyroidism 


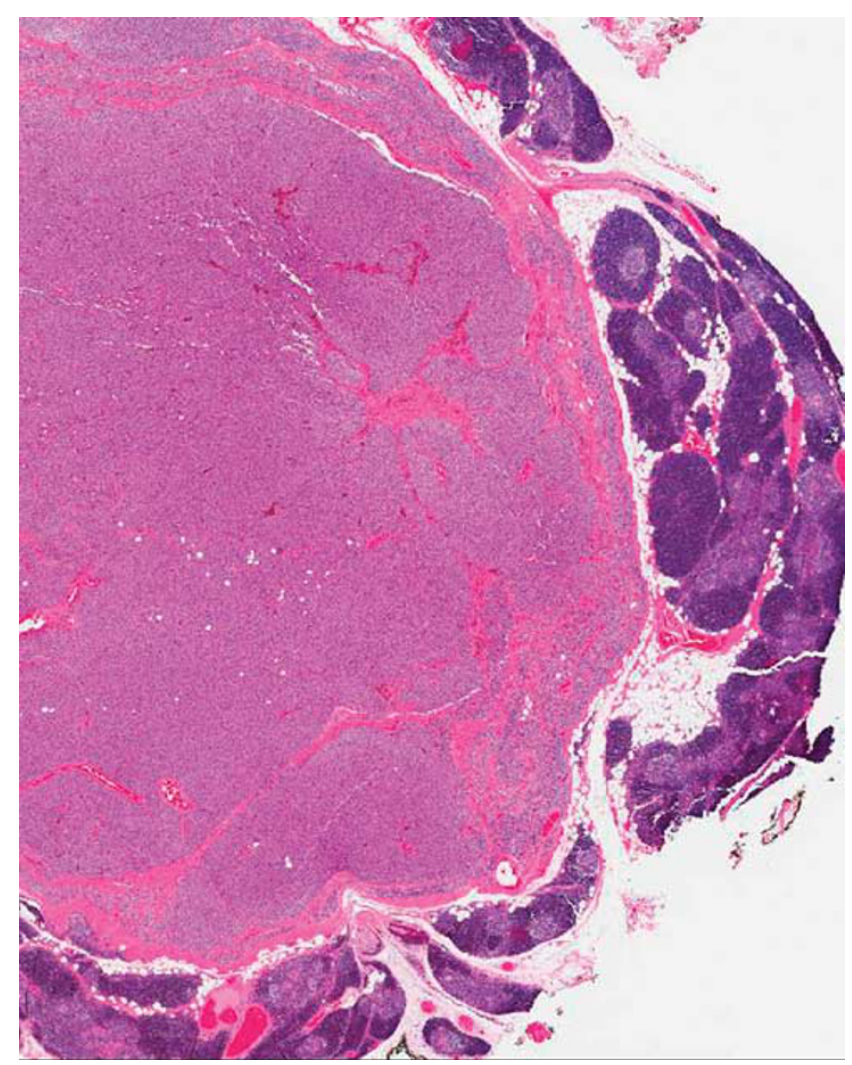

Figure 9 Intrathymic parathyroid adenoma. This noninvasive tumor has areas of fibrous banding.

(S-HPT) ${ }^{38}$ Among heritable cases of hyperparathyroidism, PT-CA has been reported in $\sim 15 \%$ of patients with the HPT-JT syndrome ${ }^{39}$ (Table 1). An increased risk of PT-CA has also been reported in patients with familial isolated hyperparathyroidism. ${ }^{40}$ PT-CA occurs rarely in $\mathrm{MEN1}^{41}$ and a single case has been reported in a patient with type 2A MEN (MEN2A). ${ }^{42}$

In contrast to the 3-4:1 predominance of parathyroid adenomas in women, PT-CA has a roughly equal male to female sex ratio. ${ }^{36}$ Moreover, PT-CA tends to occur $\sim 10$ years earlier than parathyroid adenoma. Generally, serum calcium values and PTH levels are higher in patients with carcinomas than adenomas, and patients with PT-CA are more likely to have palpable cervical masses and concomitant bone and kidney disease. Less than $10 \%$ of PT-CAs are nonfunctional. ${ }^{43}$

The pathological diagnosis of PT-CA is challenging with considerable interobserver diagnostic variability. In some series, a significant proportion of cases that recur and/or metastasize are classified as benign at first presentation. ${ }^{44}$ On the other hand, only a small proportion of cases classified initially as PT-CA behave as true malignancies. ${ }^{45}$ Whether the latter cases represent carcinomas cured by simple excision is unknown.

Parathyroid carcinomas are typically larger than adenomas and are often adherent to the surrounding soft tissues or thyroid gland ${ }^{37,46,47}$ (Figures 6 and 7).

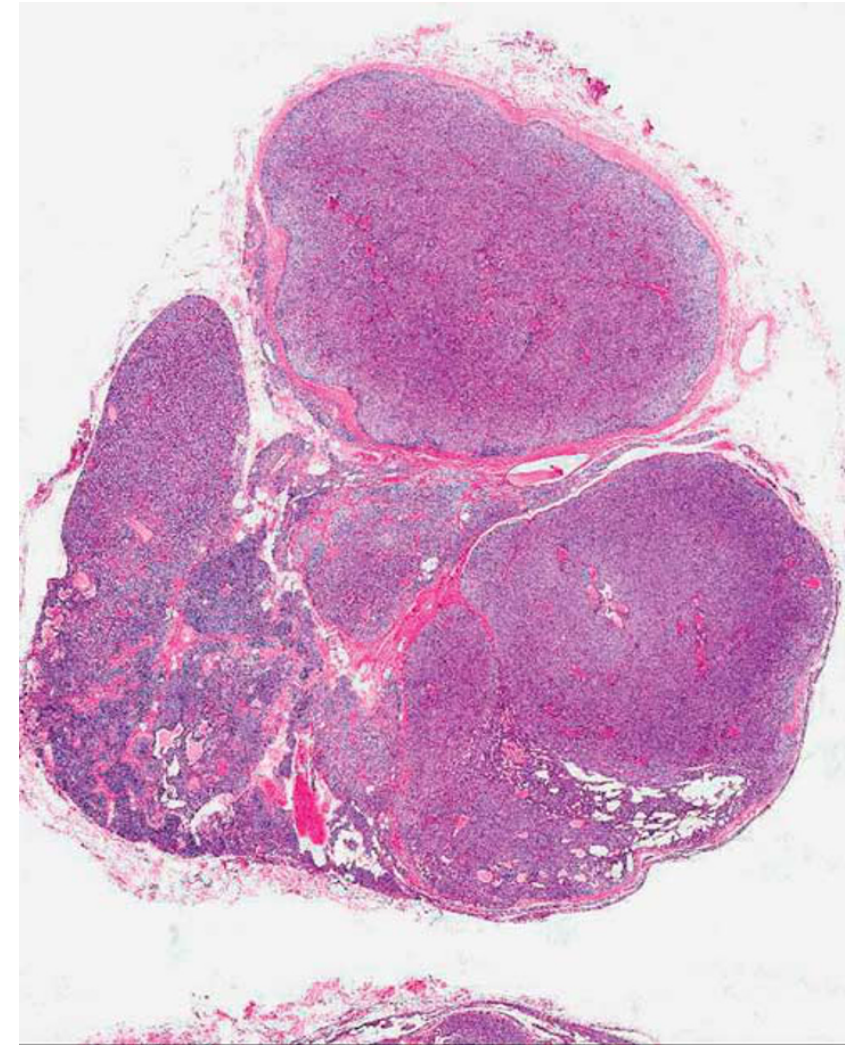

Figure 10 Multinodular parathyroid hyperplasia from a patient with MEN1.

The diagnosis of malignancy should be restricted to those tumors with evidence of invasive growth involving adjacent structures, including the thyroid and soft tissues, (Figure 6b) blood vessels (Figure 6c) or perineural spaces (Figure 6d), or to those tumors with documented metastases (Figure 8a and b). Fibrous band formation, although common in carcinomas (Figure 6a), is insufficient for the diagnosis of malignancy as fibrosis also occurs in adenomas, particularly those of large size or with cystic change. Similarly, mitotic activity is common in PT-CAs (Figure 7a and b) and is also relatively common in adenomas; however, atypical mitoses usually indicate the presence of malignancy (Figure $7 \mathrm{~b}$ ). As noted by Bondeson et al, ${ }^{48}$ the frequency of mitoses in PT-CAs did not exceed the values in benign parathyroid tumors. However, a substantial proportion of carcinomas in Bondeson's series had a markedly higher mitotic rate that was prognostically significant with respect to tumor aggressiveness. Analysis of proliferative fractions with $\mathrm{Ki}-67$ has shown higher values in PT-CAs (6-8.4\%) than in adenomas $(2-3.3 \%)$, but the overlap in equivocal cases has limited the usefulness of this approach. ${ }^{17-19}$ As compared with adenomas, carcinomas have a three- to fourfold decrease in p27 expression. These findings have suggested that low p27 and high Ki-67 scores may be useful in the discrimination of adenomas and carcinomas. ${ }^{19}$ 
Most carcinomas have a solid growth pattern with tumor cells arranged in cohesive cell masses (Figures 7a and b), whereas others have a nesting or trabecular growth pattern. Foci of necrosis may be present (Figure 7c). Bondeson et al ${ }^{48}$ noted areas of coagulative necrosis in approximately one-third of carcinomas. However, necrosis may also be present in adenomas, particularly those of large size. There is considerable variation in the cytological composition of PT-CAs. In the series of cases reported by Bondeson et al, ${ }^{48} 50 \%$ of the cases consisted almost entirely of chief cells, whereas oncocytes predominated in $11 \%$. Eighteen percent had an admixture of chief cells and oncocytes, whereas a few tumors were composed of water-clear cells. The remaining tumors were composed of transitional oncocytes or vacuolated chief cells. There is generally mild-tomoderate nuclear atypia, but some tumors may be cytologically indistinguishable from adenomas (Figures 7a, 8a and b). Data from the National Cancer Database indicate that nearly $90 \%$ of PT-CAs are well or moderately differentiated. ${ }^{49}$ In Bondeson et $a t^{48}$ series, approximately two-thirds of the carcinomas exhibited cytological atypia. However, a subset of PT-CAs may exhibit considerable nuclear pleomorphism with macronucleoli. In summary, the presence of scattered foci of coagulative necrosis in addition to macronucleoli and mitotic activity in excess of 5 per 50 high-power microscopic fields constitutes a triad indicative of a high risk of malignant behavior ${ }^{48}$ (Figure $7 \mathrm{~b}$ and $\mathrm{c}$ ). The most common metastatic sites include cervical lymph nodes, lung (Figure 8a and b) and liver.

Several groups have shown LOH on chromosome $13 \mathrm{q}$, a region that includes both $R B$ and $B R C A 2$ in PT-CAs. Cryns et al ${ }^{50}$ reported that 11 of 11 specimens from patients with these tumors lacked an RB allele, whereas only 1 of 19 adenomas lacked an RB allele. Correlative immunohistochemical studies showed a complete or predominant absence of RB in carcinomas, whereas none of the adenomas had abnormal staining patterns. However, subsequent immunohistochemical studies have failed to confirm these observations. ${ }^{51}$ The contribution of $R B$ and BRCA2 to the development of parathyroid malignancies has been controversial. In a recent study, $\mathrm{LOH}$ for at least one marker of the $R B$ allele was found in 6 of 6 carcinomas, whereas $\mathrm{LOH}$ for $B R A C 2$ was found in 3 of 5 cases. ${ }^{52}$ In the same series, $\mathrm{LOH}$ of $R B$ and BRCA2 was shown in $28.8 \%$ and $17.4 \%$ of adenomas, respectively. Direct sequencing studies of carcinomas that showed $\mathrm{LOH}$ of $R B$ or BRCA2 were negative for microdeletions, insertions or point mutations of either gene. ${ }^{53}$ These workers concluded that neither $R B$ nor $B R C A 2$ were likely to act as tumor suppressor genes in carcinomas. However, these results do not exclude the possibility that decreased $R B$ function in carcinomas, whether secondary or occurring as a result of epigenetic effects, may have a role in tumor development.

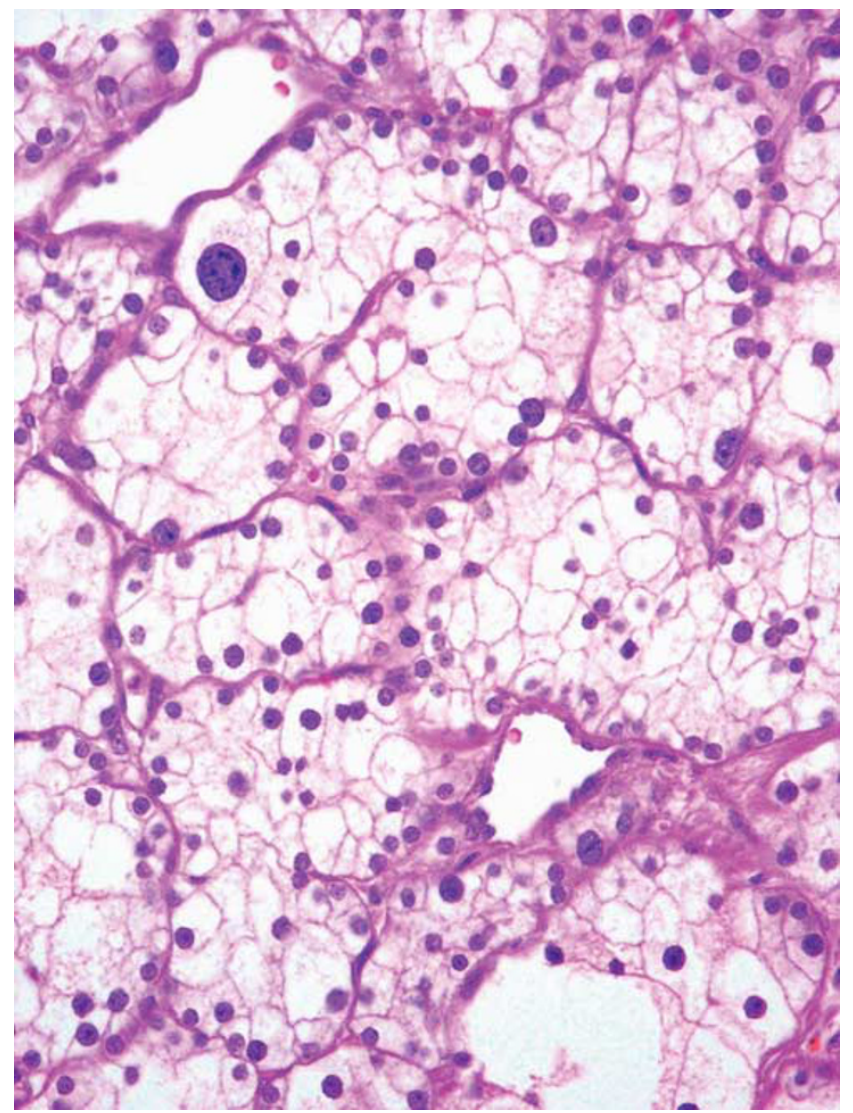

Figure 11 Water-clear hyperplasia. The cells have abundant vacuolated cytoplasm with occasional enlarged and hyperchromatic nuclei.

The HPT-JT syndrome is a rare autosomal dominant syndrome characterized by hyperparathyroidism and fibro-osseous lesions of the mandible and maxilla. Affected patients may also have evidence of a variety of renal lesions including cysts, hamartomas, renal cell carcinoma and Wilms' tumors. ${ }^{39,54}$ Hyperparathyroidism is due to the presence of multiple adenomas, some of which are cystic. Approximately $10-15 \%$ of affected patients have PT-CA. Mutations of the HRPT2 gene (1q25-q32), which encodes parafibromin, are responsible for the development of the syndrome. ${ }^{55}$

The HRPT2 gene (1q25-q32) was first implicated in the development of sporadic PT-CAs in 2003. ${ }^{56,57}$ These mutations were predicted to inactivate the parafibromin protein. Shattuck et al further showed that a subset of patients who were positive for somatic mutation of this gene were also positive for a germline mutation of the same gene. This finding suggested that a subset of patients with apparent sporadic PT-CAs carried germline mutations of the HRPT2 gene and might have the HPT-JT syndrome or a forme fruste of the syndrome. Patients with PTCA, therefore, should have jaw and kidney imaging studies. If the HPT-JT syndrome is diagnosed, family members should undergo molecular testing and imaging studies. 

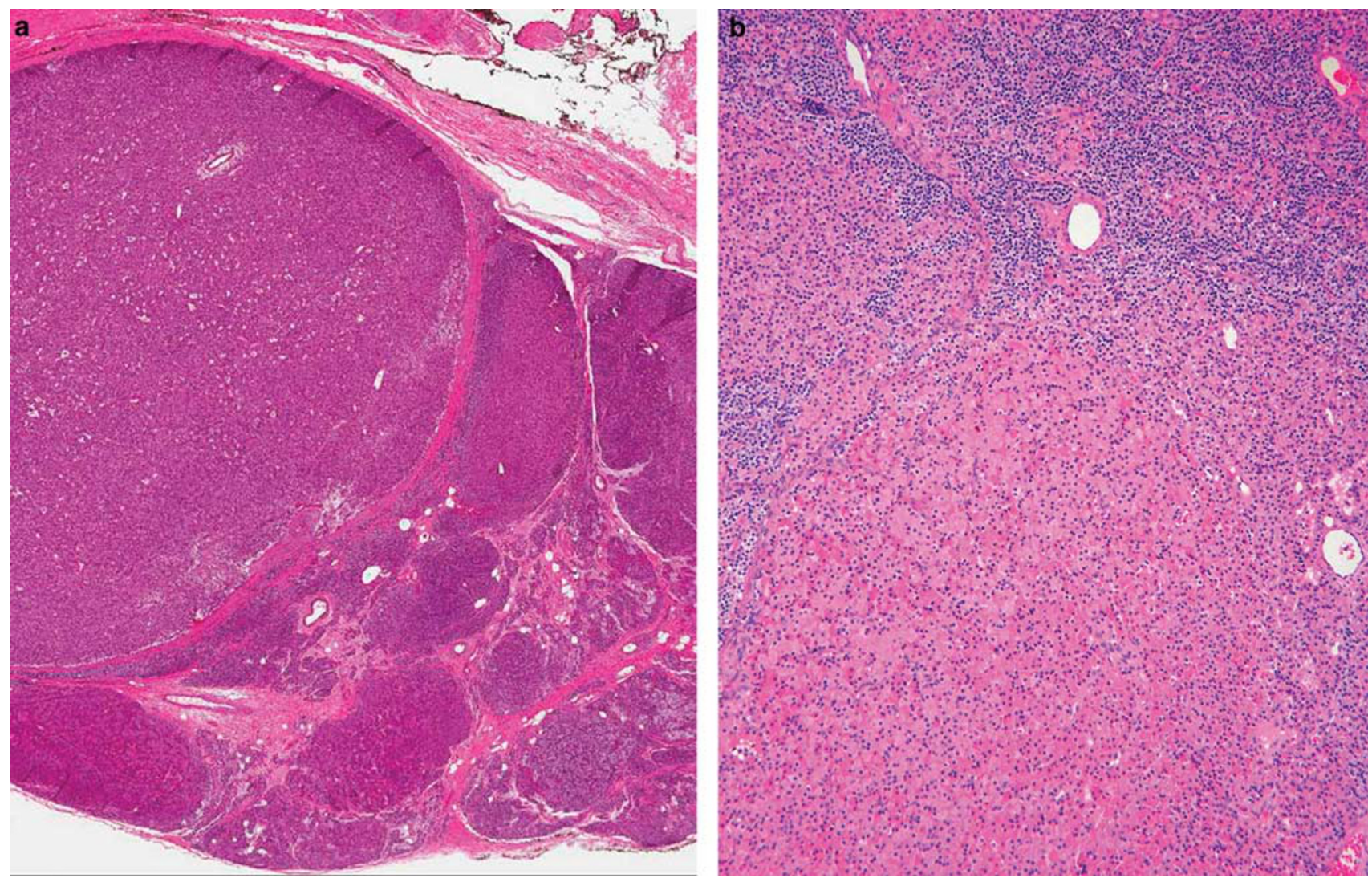

Figure 12 (a) Secondary parathyroid hyperplasia. This gland has a multinodular appearance. The largest nodule is surrounded by a fibrous capsule. (b) Secondary parathyroid hyperplasia. This field contains an oncocytic nodule.

Loss of parafibromin expression was reported as a marker for PT-CA by Tan et al ${ }^{58}$ These workers noted that loss of parafibromin nuclear immunoreactivity had a $96 \%$ sensitivity and a $99 \%$ sensitivity for the diagnosis of this tumor. Parathyroid adenomas associated with the HPT-JT syndrome have also been negative. Similar results have been reported by other workers. ${ }^{59,60}$ However, in our own experience, loss of parafibromin staining has been observed in some adenomas unassociated with the HPT-JT syndrome, whereas some PT-CAs have been positive. ${ }^{61}$ On the basis of a detailed literature review, $46 \%$ of PT-CAs have been reported as parafibromin negative, whereas $88 \%$ of cases have been reported as negative and/or weakly positive. Some of the differences in the frequency of negativity are undoubtedly related to case selection criteria, differences in primary antibodies and retrieval methods and differing criteria for the assessment of reactivity patterns. Interestingly, parafibromin has been shown in metastatic PT-CAs in patients with renal failure. ${ }^{62}$ Despite these reservations, lack of parafibromin staining offers promise as a marker of parathyroid malignancy. ${ }^{63}$ Additional markers for the diagnosis of PT-CA include galectin-3 ( $\uparrow$ expression),${ }^{64}$ PGP 9.5 ( $\uparrow$ expression $)^{65}$ and APC (loss);66 however, the utility of these markers requires additional investigation.

\section{Atypical adenoma}

Atypical adenomas of the parathyroid gland are a controversial entity ${ }^{67}$ Although these tumors have some of the features of carcinomas (banding fibrosis, mitotic activity, trabecular growth, adherence of tumor to adjacent soft tissues or thyroid and entrapment of lesional cells into the surrounding capsule), they lack unequivocal evidence of invasive growth $^{68,69}$ (Figure 9). Patients with atypical adenomas generally present with calcium levels intermediate between those of adenomas and carcinomas. ${ }^{68,69}$ On the basis of studies reported in the literature and our own observations, atypical adenomas pursue a benign clinical course. ${ }^{68}$ The molecular phenotype of atypical adenomas is intermediate between that of adenomas and carcinomas. Stojadinovic et al..$^{70}$ reported that the phenotype p27 $(+)$, bcl2 (+), Ki-67 (-) and mdm (+) was present in $76 \%$ and $29 \%$ of typical adenomas and atypical adenomas, respectively, and in no cases of carcinoma. However, other workers have failed to confirm some of these observations. ${ }^{71}$

\section{Chief cell hyperplasia}

Primary chief cell hyperplasia represents an absolute increase in parathyroid parenchymal cell mass 
involving multiple parathyroid glands in the absence of a known stimulus for PTH hypersecretion. ${ }^{72}$ This disorder was first recognized by Cope et $a l^{73}$ in 1958. Primary chief cell hyperplasia occurs sporadically in $75 \%$ of cases, whereas $25 \%$ of cases are heritable. ${ }^{74}$ The proportion of heritable cases is likely to increase with the use of molecular diagnostic approaches for classification of hyperparathyroid states. The predominant cell type, as the name implies, is the chief cell, although variable numbers of oncocytes and transitional oncocytes are observed. The glands are increased in weight and have an increased ratio of parenchymal cells to fat. The enlargement of the glands is symmetric in $\sim 50 \%$ of the cases and is asymmetric in the remainder. Although some cases of chief cell hyperplasia have a diffuse pattern of growth, other cases of hyperplasia, particularly in those occurring in MEN1, are nodular and may have a rim of normocellular parathyroid tissue at their peripheries (Figure 10). Heritable forms of HPT include MEN1, ${ }^{75}$ MEN2, ${ }^{76}$ familial hypocalciuric hypercalcemia $(\mathrm{FHH}){ }^{74}$ neonatal severe hyperparathyroidism, ${ }^{74}$ the HPT-JT syndrome, ${ }^{39,54}$ familial isolated hyperparathyroidism (FIHPT) ${ }^{77}$ and familial hypercalcemic hypercalcuria ${ }^{78}$ (Table 1 ).

The MEN1 syndrome is inherited as a autosomal dominant trait that is characterized by the development of multifocal parathyroid tumors (90\% of cases), gastroenteropancreatic neuroendocrine tumors, pituitary adenomas and a variety of other tumors. ${ }^{75}$ This syndrome occurs as a result of germline mutations that are spread over the entire coding and intronic regions of the MEN1 gene, with more than 400 different recognized sites. The development of parathyroid and other tumors in the syndrome occurs as a result of inactivation of the wild-type allele at the somatic level. Although the parathyroid disease has been classified as hyperplasia, the individual parathyroid lesions represent clonal proliferations that are more closely related to adenomas. ${ }^{21,79,80}$ For this reason, it may be preferable to refer to these cases as 'multiglandular parathyroid disease' rather than hyperplasia. Similar results have been reported by Arnold et $a^{81}$ in a series of 16 patients with nonfamilial primary chief cell hyperplasia.

Multiple endocrine neoplasia 2A is an autosomal dominant trait characterized by the development of C-cell hyperplasia and medullary thyroid carcinoma, pheochromocytomas and chief cell hyperplasia (20-30\% of cases). ${ }^{76}$ Dominant activating mutations of the RET oncogene (10q11.2) are responsible for the development of MEN2A, MEN2B and isolated familial medullary thyroid carcinoma. Parathyroid abnormalities do not occur in the MEN2B syndrome.

Familial hypocalciuric hypercalcemia is an autosomal dominant trait and occurs most frequently as a result of loss of function mutations of the CaSR gene on $3 q$ 21.1. ${ }^{74}$ Neonatal severe hyperparathyr-

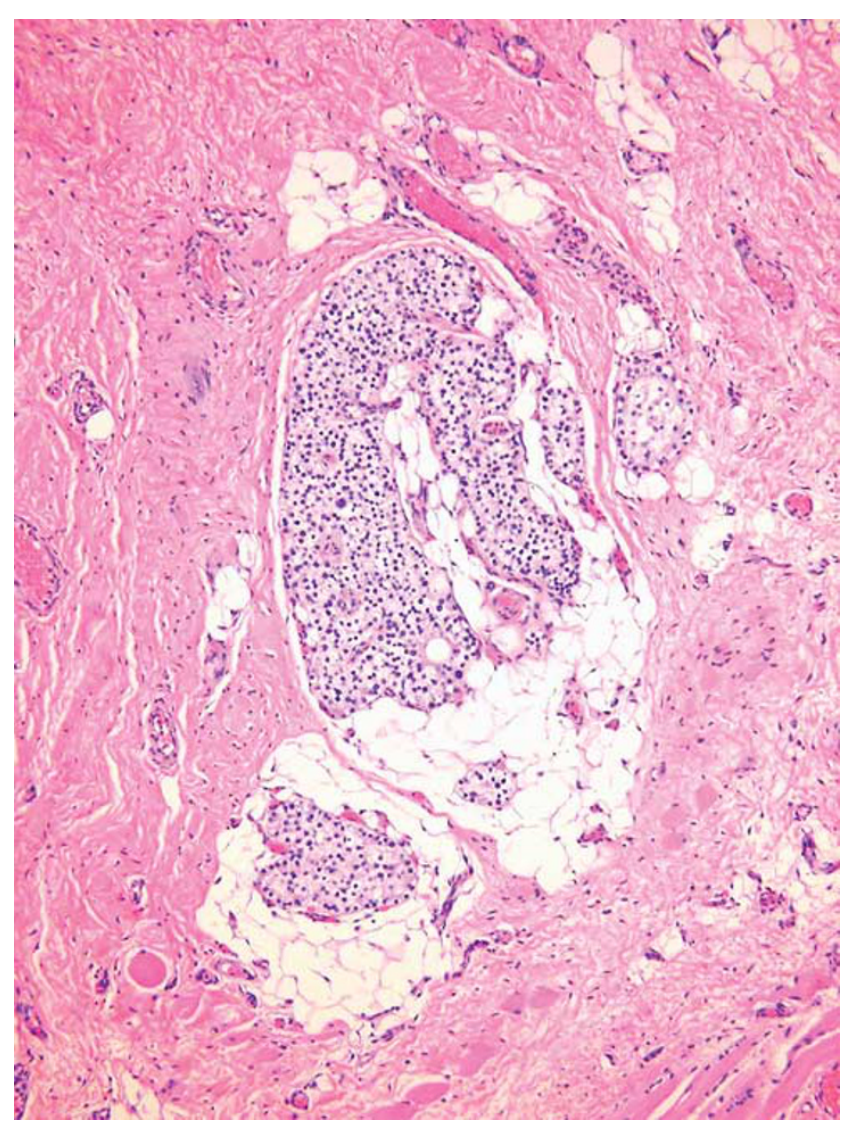

Figure 13 Parathyromatosis. This patient with primary chief cell hyperplasia developed recurrent hyperparathyroidism after subtotal parathyroidectomy. Multiple foci of parathyroid chief cells surrounded by areas of fibrosis were present in the cervical soft tissue after re-exploration.

oidism represents the homozygous form of FHH. Familial isolated hyperparathyroidism is characterized by chief cell hyperplasia and has been associated with mutations of MEN1, CaSR and HRPT2. ${ }^{77}$ Familial hypercalcemic hypercalciuria/ autosomal dominant mild hyperparathyroidism is an exceptionally rare disorder due to an inactivating mutation in the CaSR gene. ${ }^{78}$

\section{Primary water-clear cell hyperplasia}

Primary water-clear cell hyperplasia is a rare disorder that was first recognized in 1934 by Albright et al. ${ }^{82}$ In contrast to chief cell hyperplasia, primary water-clear cell hyperplasia has no known association with the heritable hyperparathyroidism syndromes. The degree of hypercalcemia is generally greater than that seen in patients with chief cell hyperplasia. There is a considerable variation in the size and weight of the glands, with total glandular weights varying between 1 and $60 \mathrm{~g}$. All four glands are usually involved, although the upper glands tend to be larger than the lower glands. Affected glands are frequently cystic and hemorrhagic. Microscopically, cytoplasmic clearing is due to the 
presence of numerous small vacuoles that are derived from the Golgi apparatus ${ }^{83}$ (Figure 11). The nuclei are generally round and regular with dense chromatin; however, occasional cells with enlarged and hyperchromatic nuclei may be evident. Kuhel et al reported a case of synchronous water-clear cell adenoma involving both upper parathyroid glands. ${ }^{84}$ Despite the fact that the two lesions were clonal on the basis of molecular studies, the possibility that this case represented asymmetric hyperplasia could not be entirely ruled out.

\section{Secondary and tertiary hyperparathyroidism}

Secondary hyperparathyroidism represents an adaptive increase in the synthesis and secretion of PTH that results from hypocalcemia of diverse etiologies, including chronic renal failure, vitamin $\mathrm{D}$ deficiency and intestinal malabsorption states. ${ }^{72}$ Tertiary hyperparathyroidism refers to the development of autonomous parathyroid hyperfunction patients with preexisting S-HPT. Pathologically, these disorders are associated with increased glandular weight and cellularity. Patients with S-HPT generally have greater uniformity in gland size than patients with P-HPT, particularly in the early stages of this disease. With further progression the glands often assume a multinodular configuration with areas of hemorrhage, cyst formation, fibrosis and chronic inflammation (Figure 12a). As a result, the distinction of such cases from PT-CA is sometimes difficult. The presence of multiglandular disease, the absence of vascular invasion and the appropriate clinical history are all helpful in making this distinction. Chief cells predominate in early phases of the disease, whereas oncocytes often represent the dominant cell population in advanced cases (Figure 12b). In all probability, the earliest phases of secondary hyperplasia are polyclonal lesions. A large majority of patients with chronic renal failure who require surgery have clonal parathyroid lesions. ${ }^{81}$ Interestingly, histopathological categories of nodular versus diffuse hyperplasia are not useful predictors of clonal status.

\section{Parathyromatosis}

Developmental rests of parathyroid tissue are relatively common in the soft tissues of the mediastinum and neck, often in proximity to normal parathyroid glands. In patients with primary or secondary parathyroid hyperplasia, the rests may also become hyperplastic, a phenomenon that has been termed 'parathyromatosis'. ${ }^{85}$ Hyperplastic rests may be responsible for persistent or recurrent hypercalcemia after parathyroidectomy ${ }^{86}$ (Figure 13). A second mechanism for the development of parathyromatosis is seeding of the operative field during parathyroidectomy or incomplete excision of a hyperplastic or adenomatous parathyroid gland. ${ }^{86}$

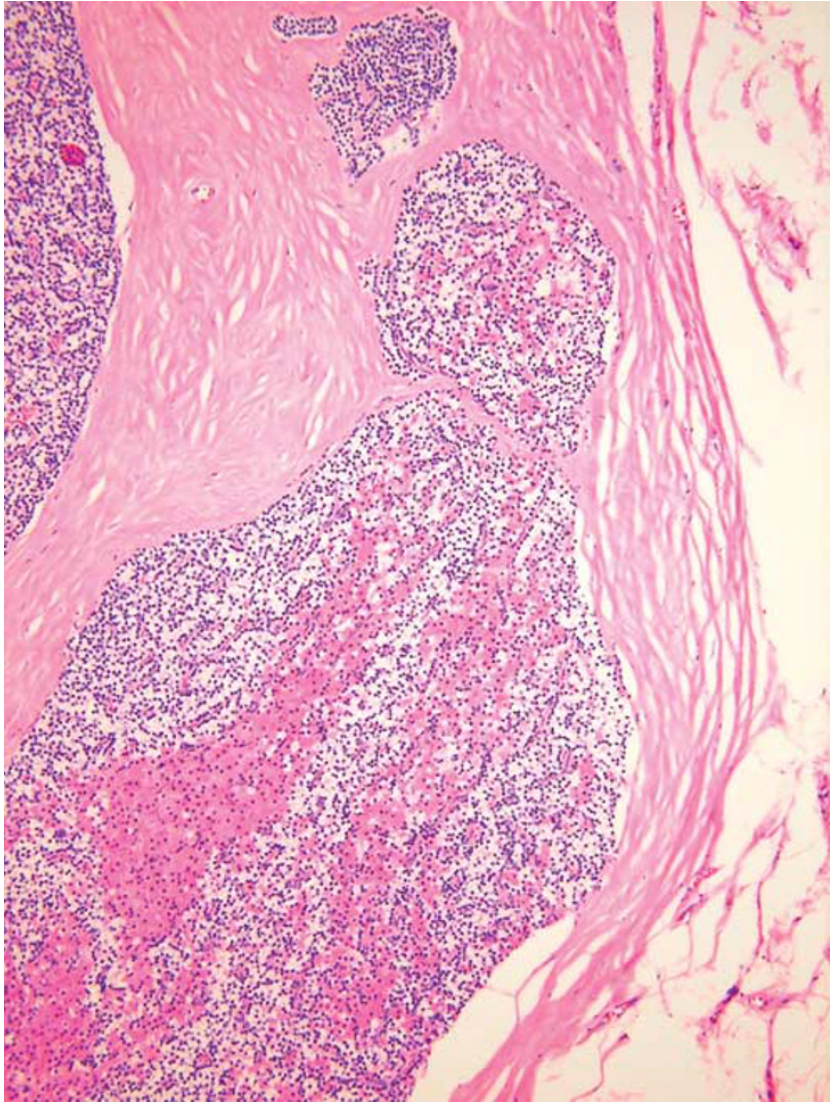

Figure 14 Hyperplastic parathyroid tissue after autotransplantation of parathyroid tissue in the forearm of a patient with secondary hyperparathyroidism treated by total parathyroidectomy. Nodules of chief cells and oncocytes surrounded by fibrous bands were present in the subcutaneous tissue.

The distinction of parathyromatosis from PT-CA is challenging. In patients with previously untreated primary or secondary hyperplasia, foci of parathyromatosis are unassociated with desmoplasia. However, in patients with previous surgery, parathyromatosis may be associated with considerable fibrosis, invasion of skeletal muscle and soft tissues and mitotic activity, features that are similar to parathyroid autotransplants (Figure 14). Vascular invasion, on the other hand, is absent. Recent studies indicate that the molecular profiles of parathyromatosis are similar to those of benign parathyroid tumors with respect to expression of parafibromin, Ki-67, RB and galectin-3. ${ }^{71}$

\section{Disclosure/conflict of interest}

The author declares no conflict of interest.

\section{References}

1 Zink AR, Panzer S, Fesq-Martin M, et al. Evidence for a 7000-year old case of primary hyperparathyroidism. JAMA 2005;293:40-42. 
2 Carney AJ. The glandulae parathyroideae of Ivar Sandström: contributions from two continents. Am J Surg Pathol 1996;20:1123-1144.

3 Organ CH. The history of parathyroid surgery 18501996: the excelsior surgical society 1998, Edward G. Churchill lecture. J Am Coll Surg 2000;191:284-299.

4 Melton LJ. The epidemiology of primary hyperparathyroidism in North America. J Bone Miner Res 2002; 17(Suppl 2):N12-N17.

5 Fraser WD. Hyperparathyroidism. Lancet 2009;374: 145-158.

6 Wermers RA, Khosia S, Atkinson EJ, et al. Incidence of primary hyperparathyroidism in Rochester, Minnesota, 1993-2001: an update on changing epidemiology of the disease. J Bone Miner Res 2006;21:171-177.

7 Monchik JM. Normocalcemic hyperparathyroidism. Surgery 1995;118:917-923.

8 DeLellis RA, Mazzaglia P, Mangray S. Primary hyperparathyroidism: a current perspective. Arch Pathol Lab Med 2008;132:1251-1262.

9 Molinari AS, Irvin III GL, Deriso GT, et al. Incidence of multiglandular disease in primary hyperparathyroidism determined by parathyroid hormone secretion. Surgery 1996;120:934-936.

10 Van Houten JN, Yu N, Rimm D, et al. Hypercalcemia of malignancy due to ectopic transactivation of the parathyroid hormone gene. J Clin Endocrinol Metab 2006;91:580-583.

11 Lumachi F, Brunello A, Roma A, et al. Cancer induced hypercalcemia. Anti Cancer Res 2009;29:1551-1555.

12 DeLellis RA. Tumors of the Parathyroid Gland. Atlas of Tumor Pathology, 3rd series, fascicle 6 Armed Forces Institute of Pathology: Washington, DC, 1993.

13 Grimelius L, DeLellis RA, Bondeson L, et al. Parathyroid adenoma. In: DeLellis RA, Lloyd RV, Heitz PU, Eng C (eds). Pathology and Genetics of Tumours of Endocrine Organs. World Health Organization Classification of Tumours, IARC Press: Lyon, France, 2004, pp 128-132.

14 Verdonk CA, Edis AJ. Parathyroid 'double adenomas': fact or fiction? Surgery 1981;80:523-526.

15 Milas M, Wagner K, Easley KA, et al. Double adenomas revisited: nonuniform distribution favors enlarged superior parathyroids (fourth pouch disease). Surgery 2003;134:995-1003.

16 Snover D, Foucar K. Mitotic activity in benign parathyroid disease. Am J Clin Pathol 1981;75:345-347.

17 Abbona CG, Papotti M, Gasparri G, et al. Proliferative activity in parathyroid tumors as detected by Ki-67 immunostaining. Hum Pathol 1995;26:135-138.

18 Vargas MP, Vargas HI, Keiner DE, et al. The role of prognostic markers (MIB-1, RB and bcl-2) in the diagnosis of parathyroid tumors. Mod Pathol 1997;10:12-17.

19 Erickson LA, Jin L, Wollan P, et al. Parathyroid hyperplasia, adenomas and carcinomas: differential expression of p27 Kip1 protein. Am J Surg Pathol 1999; 23:288-295.

20 Isotalo PA, Lloyd RV. Presence of birefringent crystals in useful in distinguishing thyroid from parathyroid gland tissues. Am J Surg Pathol 1999; 23:288-295.

21 Arnold A, Shattuck TM, Mallya SM, et al. Molecular pathogenesis of primary hyperparathyroidism. J Bone Miner Res 2002;17:N30-N36.

22 Westin G, Björklund P, Akerström G. Molecular genetics of parathyroid disease. World J Surg 2009;33: 2224-2233.
23 Chandrasekharappa SC, Guru SC, Manickham P, et al. Positional cloning of the gene for multiple endocrine neoplasia type1. Science 1997;276:404-407.

24 Lemmens I, Van deVen WJ, Kas K, et al. Identification of the multiple endocrine neoplasia type 1 (MEN1) gene. The European Consortium on MEN1. Hum Mol Genet 1997;6:1177-1183.

25 Imanishi Y. Molecular pathogenesis of tumorigenesis in sporadic parathyroid adenomas. J Bone Miner Metab 2002;20:190-195.

26 Palanisamy N, Imanishi Y, Rao $\mathrm{PH}$, et al. Novel chromosomal abnormalities identified by comparative genomic hybridization in parathyroid adenomas. J Clin Endocrinol Metab 1998;83:1766-1770.

27 Greene AB, Butler RS, McIntyre S, et al. National trends in parathyroid surgery from 1998 to 2008: a decade of change. J Am Coll Surg 2009;209:332-343.

28 Johnson NA, Tublin ME, Ogilve JB. Parathyroid imaging: technique and role in the preoperative evaluation of primary hyperparathyroidism. Am J Roentgenol 2007;188:1706-1715.

29 Taillefer R, Boucher Y, Potvin C, et al. Detection and localization of parathyroid adenomas in patients with hypoparathyroidism using a single radionuclide imaging procedure with technetiuym-99m-sestamibi (double phase study). J Nucl Med 1992;33:1801-1807.

30 Irvin III GL, Dembrow VD, Prudhomme DL. Operative monitoring of parathyroid gland hyperfunction. Am J Surg 1991;162:299-302.

31 Udelsman R. Six hundred fifty-six consecutive explorations for primary hyperparathyroidism. Ann Surg 2002;235:665-670.

32 Carneiro DM, Solorzano CC, Irvin III GL. Recurrent disease after limited parathyroidectomy for sporadic primary hyperparathyroidism. J Am Coll Surg 2004; 199:849-853.

33 Garner SC, Leight Jr GS. Initial experience with intraoperative PTH determinations in the surgical management of 130 consecutive cases of primary hyperparathyroidism. Surgery 1999;126:1132-1137.

34 Vignali E, Picone A, Materazzi G, et al. A quick intraoperative parathyroid hormone assay in the surgical management of patients with primary hyperparathyroidism: a study of 206 consecutive cases. Eur J Endocrinol 2002;146:783-788.

35 Biskobing DM. Significance of elevated PTH after parathyroidectomy. Endocrine Pract 2009;16:112-117.

36 Marcocci C, Cetani F, Rubin MR, et al. Review: parathyroid carcinoma. J Bone Miner Res 2008;23: 1869-1880.

37 DeLellis RA. Parathyroid carcinoma. Adv Anat Pathol 2004;12:53-61.

38 Boyle NH, Ogg CS, Hartley RB, et al. Parathyroid carcinoma secondary to prolonged hyperplasia in chronic renal failure and celiac disease. Eur J Surg Oncol 1999;25:100-103.

39 Chen JD, Morrison C, Zhang C, et al. Hyperparathyroidism-jaw tumor syndrome. J Int Med 2003;253: 634-642.

40 Wassif WS, Moniz CF, Friedman E, et al. Familial isolated hyperparathyroidism: a distinct genetic entity with an increased risk of parathyroid cancer. J Clin Endocrinol Metab 1993;77:1485-1489.

41 Agah A, Carpenter R, Bhattacharya S, et al. Parathyroid carcinoma in multiple endocrine neoplasia type 1 (MEN1) syndrome: two case reports of an unrecognized entity. J Endocrinol Invest 2007;30:145-149. 
42 Jenkins PJ, Satta MA, Simmgen M, et al. Metastatic parathyroid carcinoma in MEN2A syndrome. Clin Endocrinol (Oxf) 1997;47:747-751.

43 Wilkins BJ, Lewis JS. Non-functional parathyroid carcinoma: a review of the literature and report of a case requiring extensive surgery. Head Neck Pathol 2009;3:140-149.

44 Sandelin K, Tullgen D, Farnebo O. Clinical course of parathyroid cancer. World J Surg 1994;18:594-598.

45 Ippolito G, Plazzo FF, Sebag F, et al. Intraoperative diagnosis and treatment of parathyroid cancer and atypical parathyroid adenoma. Br J Surg 2007;94: $566-570$.

46 Schantz A, Castleman B. Parathyroid carcinoma. A study of 70 cases. Cancer 1973;31:600-605.

47 Bondeson L, Grimelius L, DeLellis RA, et al. Parathyroid carcinoma. In: DeLellis RA, Lloyd RV, Heitz PU and Eng C (eds). Pathology and Genetics of Tumours of Endocrine Organs. WHO classification of Endocrine Tumours, IARC Press: Lyon, 2004. pp 124-127.

48 Bondeson L, Sandelin K, Grimelius L. Histopathological variables and DNA cytometry in parathyroid carcinomas. Am J Surg Pathol 1993;17:820-829.

49 Hundahl SA, Fleming ID, Fremgen AM, et al. Two hundred eighty-six cases of parathyroid carcinoma treated in the US between 1985-1995. A national cancer data base report. Cancer 1999;86:538-544.

50 Cryns VK, Thor A, Xu HJ. Loss of the retinoblastoma tumor suppressor gene in parathyroid carcinoma. N Eng J Med 1994;330:757-761.

51 Lloyd RV, Carney JA, Ferreiro JA, et al. Immunohistochemical analysis of the cell cycle associated antigens Ki-67 and retinoblastoma protein in parathyroid carcinomas and adenomas. Endocr Pathol 1995;6: 279-287.

52 Cetani F, Pardi E, Vlacava P, et al. A reappraisal of the $\mathrm{Rb}-1$ gene abnormalities in the diagnosis of parathyroid carcinoma. Clin Endocrinol 2004;60:99-106.

53 Shattuck TM, Kim TS, Costa J, et al. Mutational analysis of $\mathrm{RB}$ and BRCA2 as candidate tumor suppressor genes in parathyroid carcinomas. Clin Endocrinol 2003;59:180-189.

54 Teh BT, Sweet KM, Morrison CD. Hyperparathyroidism-jaw tumour syndrome. In: DeLellis RA, Lloyd RV, Heitz PU and Eng C (eds). Pathology and Genetics of Tumours of Endocrine Organs. WHO Classification of Endocrine Tumours, IARC Press: Lyon, 2004. pp 228-229.

55 Carpten JD, Robbins CM, Villablanca A, et al. HRPT2 encoding parafibromin is mutated in hyperparathyroidism-jaw tumor syndrome. Nat Genet 2002;32: $676-680$.

56 Howell VM, Haven CJ, Kahnoski K, et al. HRPT2 mutations are associated with malignancy in sporadic parathyroid tumors. J Med Genet 2003;40:657-663.

57 Shattuck TM, Valimaki S, Obara T, et al. Somatic and germline mutations of the HRPT2 gene in sporadic parathyroid carcinoma. N Engl J Med 2003;349: 1722-1729.

58 Tan MH, Morrison C, Wang P, et al. Loss of parafibromin immunoreactivity is a distinguishing feature of parathyroid carcinoma. Clin Cancer Res 2004;10: 6629-6637.

59 Gill AJ, Clarkson A, Gimm O. Loss of nuclear expression of parafibromin distinguishes parathyroid carcinoma and hyperparathyroidism-jaw tumor associated adenoma from sporadic parathyroid adenomas and hyperplasias. Am J Surg Pathol 2006;30: 1140-1149.

60 Juhlin CC, Villablanca A, Sandelin K, et al. Parafibromin immunoreactivity; its use as an additional diagnostic marker for parathyroid tumor classification. Endocrin Relat Cancer 2007;14:501-512.

61 Mangray S, DeLellis RA. Parafibromin as a tool for the diagnosis of parathyroid tumors (letter). Adv Anat Pathol 2008;15:179.

62 Tominaga Y, Tsuzuki T, Matsuoka A, et al. Expression of parafibromin in distant metastatic parathyroid tumors in patients with advanced secondary hyperparathyroidism due to chronic kidney disease. World J Surg 2008;32:815-821.

63 Cetani F, Ambrogini E, Viacava P, et al. Should parafibromin staining replace HRTP2 gene analysis as an additional tool for histologic diagnosis of parathyroid carcinoma? Eur J Endocrinol 2007;156: 547-554.

64 Bergero N, DePompa R, Sacerdote C, et al. Galectin-3 expression in parathyroid carcinoma: immunohistochemical study of 26 cases. Hum Pathol 2005;36: 908-914.

65 Howell VM, Gill A, Clarkson A, et al. Accuracy of combined protein gene product 9.5 and parafibromin markers for immunohistochemical diagnosis of parathyroid carcinoma. J Clin Endocrinol Metab 2009;94:343-441.

66 Juhlin CC, Haglund F, Villablanca A, et al. Loss of expression for the Wnt pathway components adenomatous polyposis coli and glycogen synthase kinase 3B in parathyroid carcinomas. Int J Oncol 2009;34: 481-492.

67 Levin KE, Chew KL, Ljung BM, et al. Deoxyribonucleic acid cytometry helps identify parathyroid carcinomas. J Clin Endocrinol Metab 1988;67:779-784.

68 Guiter GE, DeLellis RA. Risk of recurrence or metastasis in atypical parathyroid adenomas. Mod Pathol 2002;15:115A.

69 Fernandez-Ranvier GG, Khanafshar E, Jensen K, et al. Parathyroid carcinoma, atypical parathyroid adenomas, or parathyromatosis? Cancer 2007;110:255-264.

70 Stojadinovic A, Hoos A, Nissar A, et al. Parathyroid neoplasms: clinical, histopathologic and tissue microarray-based molecular analysis. Hum Pathol 2003;34:54-64.

71 Fernandez-Ranvier GG, Khanafshar E, Tacha D, et al. Defining a molecular phenotype for benign and malignant parathyroid tumours. Cancer 2009;115: 334-344.

72 DeLellis RA. Tumors of the Parathyroid Gland. Atlas of Tumor Pathology. Armed Forces Institute of Pathology: Washington, DC, 1978.

73 Cope O, Keynes WM, Roth SI, et al. Primary chief cell hyperplasia of the parathyroid glands. A new entity in the surgery of hyperparathyroidism. Ann Surg 1958;148:275-388.

74 Marx SJ, Simonds WF, Agarwal SK, et al. Hereditary hyperparathyroidism in hereditary syndromes: special expressions and special management. J Bone Miner Res 2002;17(Suppl 2):N37-N43.

75 Calender A, Morrison CS, Kommioth P, et al. Multiple endocrine neoplasia type1. In: DeLellis RA, Lloyd RV, Heitz PU and Eng C (eds). Pathology and Genetics of Tumours of Endocrine Organs. WHO Classification of Endocrine Tumours, IARC Press: Lyon, 2004, pp 218-227. 
76 Gimm O, Morrison CD, Suster S, et al. Multiple endocrine neoplasia type2. In: DeLellis RA, Lloyd RV, Heitz PU and Eng C (eds). Pathology of Genetics of Tumours of Endocrine Organs. WHO Classification of Endocrine Tumours, IARC Press: Lyon, 2004, pp 211-217.

77 Simonds WF, James-Newton O, Agarwal AK, et al. Familial isolated hyperparathyroidism: clinical and genetic characterizations of 36 kindreds. Medicine 2002;81:1-26.

78 Carling T, Szabo E, Bai M, et al. Familial hypercalcemia and hypercalcuric caused by a novel mutation in the cytoplasmic tail of the calcium receptor. J Clin Endocrinol Metab 2000;85:2042-2047.

79 Friedman E, Sakaguchi K, Bale AE, et al. Clonality of parathyroid tumors in familial multiple endocrine neoplasia type 1. N Engl J Med 1989;321:213-218.

80 Thakker RV, Bouloux P, Wooding K, et al. Association of parathyroid tumors in multiple endocrine neoplasia type 1 with loss of alleles on chromosome 11. N Engl J Med 1989;321:218-224.
81 Arnold A, Brown MF, Urena P, et al. Monoclonality of parathyroid tumors in chronic renal failure and in primary parathyroid hyperplasia. J Clin Invest 1995;95: 2047-2053.

82 Albright F, Bloomberg E, Castleman B, et al. Hyperparathyroidism due to diffuse hyperplasia of all parathyroid glands rather than adenoma of one. Clinical Studies on three such cases. Arch Int Med 1934;54:35-329.

83 Roth SI. The ultrastructure of primary water-clear cell hyperplasia of the parathyroid glands. Am J Pathol 1970;61:233-248.

84 Kuhel WI, Gonzales D, Hoda SA, et al. Synchronous water clear cell double parathyroid adenomas: a hitherto uncharacterized entity. Arch Pathol Lab Med 2001;125:256-259.

85 Reddick RL, Costa JC, Marx SJ. Parathyroid hyperplasia and parathyromatosis. Lancet 1977;1:549.

86 Rattner DW, Marrone GC, Kasdon E, et al. Recurrent hyperparathyroidism due to implantation of parathyroid tissue. Am Surg 1985;149:745-748. 